\title{
The Impact of Different Output-based Task Repetition Conditions on Producing Speech Acts among Iranian Advanced EFL Learners
}

\author{
Parisa Etemadfar \\ Department of English Language, Faculty of Letters \& Humanities, Shahrekord University, Shahrekord, Iran \\ Ehsan Namaziandost \\ Department of English, Faculty of Humanities, Shahrekord Branch, Islamic Azad University, Shahrekord, Iran \\ Reza Banari \\ Department of English, Baghmalek Branch, Islamic Azad University, Baghmalek, Iran
}

\begin{abstract}
This examination inspected the effects of different output-based task reiteration conditions with respect to producing EFL students' speech acts. Three groups were incorporated into this investigation: (1) the explicit task-repetition (ETR) group, (2) the implicit task-repetition (ITR) group, and (3) the no-input task repetition (NTR) group. All the three groups occupied with the reiteration of output generation tasks. However, before the second execution of the task, the ETR, ITR, NTR groups received input combined with metapragmatic data, input combined with an awareness raising task, and no information separately. The outcomes demonstrated students' exhibition was factually huge from the pretest to the posttest in the ETR and ITR groups, however not in the NTR group. Besides, the analysis of contrasts over the groups in the posttest uncovered the predominance of the ETR over the ITR and NTR groups. The discoveries suggest that outputbased task repetition with input can advance EFL students' speech act production.
\end{abstract}

Index Terms - output, output-based task repetition, task repetition, speech acts

\section{INTRODUCTION}

There have been various examinations investigating interlanguage pragmatics (ILP) movements in the earlier these decades. As delineated by Rose (2005), the investigations are put in three arrangements overseeing (1) regardless of whether a specific region of pragmatics is at all open to guidance, (2) whether guidance is more valuable than simple experience, and (3) whether there are differential effects for more than one sort of instructional intervention. Moreover, Rose cases that "examines which fall into the second-rate class are presumably going to yield data that is most appropriate for scholarly purposes" (p. 390). About the second-rate class of ILP look into, the majority of the investigates have considered the productivity of express against verifiable techniques for ILP educating (Taguchi, 2015; Namaziandost, Abedi, \& Nasri, 2019; Tahmasbi, Hashemifardnia, \& Namaziandost, 2019).

Task reiteration is a famous issue in TBLT. As nearly task arranging, it is portrayed as "emphasis of the identical or to some degree adjusted assignment - paying little respect to whether the whole tasks, or parts of an assignment" (Bygate \& Samuda, 2005, p. 43). Task reiteration is made so as to intrigue EFL learners' execution on an assignment (Hashemifardnia, Namaziandost, \& Sepehri, 2018; Keshmirshekan, Namaziandost, \& Pournorouz, 2019; Sheppard, 2006) and their L2 securing (Ahmadian, 2011; Nasri, Namaziandost, \& Akbari, 2019). Worried to Sheppard's (2006) discoveries, Ellis (2009) underlines the significance of criticism and contribution preceding the second execution of a task. Comparing this line of research, the momentum research was planned to respect the effects of output-based task redundancy associated by contribution in addition to metapragmatic information, obviously improved contribution in addition to awareness raising (CR), and no contribution on creating discourse acts among EFL learners (Hashemifardnia, Namaziandost, \& Shafiee, 2018; Mirshekaran, Namaziandost, \& Nazari, 2018).

\section{REVIEW OF THE RELATED LITERATURE}

Reiteration has been considered as an unequivocal component in SLA from different perspectives. In conventional type of talking, the behavioristic point of view toward learning has summed up a major job to redundancy. Among using the measures of reiteration, expansion, and backing, the professionals of the attitude toward learning cause exercises and practices that immediate the understudy to L2 propensity arrangement (Abedi, Keshmirshekan, \& Namaziandost, 2019; Namaziandost \& Nasri, 2019b; Pica, 2011). Besides, redundancy has been talked about in the perspective on language learning as subjective expertise procurement. This attitude toward SLA accept that reiteration recoups automatization (Hosseini, Nasri, \& Afghari, 2017; Namaziandost, Nasri, \& Keshmirshekan, 2019; Van sanctum 
Branden, 2007). By introducing the task-based language instructing, task reiteration is critical in L2 educating. In such manner, Ellis (2005) views task practice or redundancy as a kind of task arranging and expresses that it contains leading an assignment earlier basic execution "with the key execution of the assignment considered as acquisition for the ensuing execution" (p. 3).

Concerning the primary class, the more prominent number of ILP examines bolster the matchless quality of express educating over verifiable instructing (Azadi, Biria, \& Nasri, 2018; Namaziandost \& Nasri, 2019a; Taguchi, 2015). For instance, the effects of express and certain educating on cutting edge German EFL learners' even minded familiarity was examined by House (1996). House reasoned that both the unequivocal and certain gathering exploited from educating. In any case, the express gathering used a huge assortment of talk markers and procedures in pretends. Besides, in a similar vein, the viability of unequivocal and understood guidance in instructing L2 Japanese down to earth schedules to starting students was looked at by Tateyama (2001). The discoveries demonstrated no huge distinction among the two instructing circumstances.

As to second class (i.e., input-based and yield based guidance), Takimoto (2009) reviewed the effect of three sorts of information-based tasks (i.e., organized info assignments with and with no unequivocal data and critical thinking tasks) in training English well-mannered interest structures to Japanese students of English. The assignments were copied so as to make the information movement increasingly viable. The outcomes demonstrated that the three treatment bunches extensively beat the control bunch on a discourse culmination test, a listening test, and an adequacy judgment test.

Likewise, Li (2012) found the impact of info put together practice with respect to recuperating precise and quick requests in L2 Chinese. 30 middle of the road level students were isolated to a concentrated preparing gathering (IT), a customary preparing gathering (RT), and a control gathering. The IT and the RT groups working on utilizing Chinese interest structures by means of modernized organized information exercises. The IT gathering working on utilizing the interest shapes twice as much as the RT gathering. In spite of the fact that the control gathering didn't get any routine with regards to the interest structures. The outcomes demonstrated that the data-based practice coordinated to the improvement of exactness in an oral discourse finish task and to the progression of speed in a down to business listening judgment task (Nasri \& Biria, 2017).

Besides, Tajeddin and Bagherkazemi (2014) checked the effects of individual and community yield on 54 intermediates Iranian EFL students' discourse demonstration generation. There was no control gathering. They reasoned that the two sorts of output affected the students' present moment and long-haul creation of discourse acts. Also, it found that collective yield is more powerful than individual output.

On the third classification (i.e., Task-based Instruction), Tajeddin et al. (2012) tried the impact of TBLT on Iranian middle EFL students' discourse demonstration generation, metapragmatic mindfulness, and sober minded selfevaluation. 75 middle of the road level EFL learners arbitrarily were separated to three groups: two exploratory groups and one control gathering. In the primary test bunch, the members were given even minded focus on discourse acts in pre-task and post-task stages. The members of the second exploratory gathering simply got pragmalinguistic and sociopragmatic input and framework during task fulfillment (Namaziandost, Nasri, Rahimi Esfahani, \& Keshmirshekan 2019; Nasri, Biria, \& Karimi, 2018). In spite of the fact that in the control bunch the members were not exposed to a down to business center. As indicated by ends all the three groups demonstrated movements in their discourse demonstration generation with no impressive distinction among. However, metapragmatic mindfulness and practical self-evaluation simply were improved in the two test groups (Namaziandost, Nasri, \& Rahimi Esfahani, 2019a).

Quickly, over the latest two decades there has been a speedy expansion of ILP interventional inquiries about. The inquiries about have drawn nearer "ordinary SLA structures of seeing and unequivocal/certain guidance, input handling, and aptitude securing and practice" (Namaziandost, Rahimi Esfahani, Nasri, \& Mirshekaran, 2018; Taguchi, 2011). Without considering the abundance of interventional inquiries about in L2 pragmatics, the potential effect of task redundancy on ILP improvement isn't tried agreeably. About as referenced above, Takimoto (2009) exhibited some proof for the effects of information put together task-type reiteration with respect to L2 students' procurement of English interest structures. Moreover, utilizing critical thinking assignments, Takimoto (2012) looked through the effects of undefined task redundancy and a similar task type reiteration on L2 realistic improvement.

Until now, no examines have studied the effect of various output-based task reiteration conditions, as operationalized in this exploration, on creating discourse acts among EFL students. Consequently, the present research was wanted to test the effect of yield put together task redundancy with respect to EFL students' capacity to deliver the discourse demonstrations of saying thanks to, saying 'sorry' and won't. As referenced over, three output-based task reiteration conditions were made, for example, ETR, ITR, and NTR. Thinking about the point of the investigation, the accompanying examination question was figured:

Do different task repetition conditions (ETR, ITR, and NTR) have differential impacts on producing speech act among Iranian advance EFL learners?

\section{METHOD}

\section{A. Participants}

The members were local speakers of British English and EFL students as members. The members were all either college learners or college graduates. Ten local speakers of British English (seven guys and three females, age extend 
23-35) and ten EFL students (4 guys and 6 females, age run 24-35) added to the development of a WDCT. Nine local speakers of British English (six guys and three females) were selected to finish the WDCT to look at its substance legitimacy. Their age ran from 24 to 83. Three flawless classes of English-real learners $(n=80)$ sat the Oxford Placement Test (OPT, Allen, 2004). The periods of the students went from 19 to 34. None of them had the experience of remaining in an English-talking nation. Twenty-three of them detailed involvement of learning English in language establishments. The members shaped three groups. Gathering 1 was arbitrarily allotted to the ETR condition $(n=26)$, bunch 2 was relegated to the ITR condition $(n=28)$, and gathering 3 was doled out to NTR condition $(n=26)$. ANOVA results showed that the three groups were homogeneous as far as EFL capability as controlled by their OPT mean scores, $\mathrm{F}(2,77)=.771, \mathrm{p}=.466$.

\section{B. Instruments}

Two instruments were utilized in the present study: The Oxford Placement Test and a Written Discourse Completion Test (WDCT).

Oxford Placement Test: The OPT comprises of tuning in and language areas and incorporates 100 things in each segment. As Allen (2004) keeps up, this test has been aligned against the levels framework given by the Common European Framework of Reference for Languages (CEF), significant universal language assessments, for example, IELTS, TOEFL, and TOEIC, and the Cambridge ESOL Examinations. With regards to the legitimacy of the OPT, Birjandi and Siyyari (2010) found a high relationship between the scores of the members in the OPT and their scores in a paper-based TOEFL.

Written Discourse Completion Test: So as to build the WDCT, the scientists arranged a pool of 36 situations (12 situations for every discourse demonstration). Some were taken from the writing (Cheng, 2005; Eisenstein \& Bodman, 1986) and some were developed by the scientists themselves. The readied situations were exposed to circumstance probability examination and metapragmatic evaluation. This instrumentation system was done among 20 members (10 EFL students and 10 local speakers of British English). Following Li (2012), for the EFL students, the situations were depicted in their local language to guarantee the lower level students' understanding. In the circumstance probability examination, the 20 members were approached to demonstrate on a 5-point scale the probability that the situations would happen in their everyday life, with 1 being the most outlandish and 5 the doubtlessly. The seven situations with the most elevated probability of event were chosen for every discourse demonstration, and a 21-thing WDCT was built.

The developed WDCT was checked on and amended by a local speaker of British English. To guarantee the substance legitimacy of the WDCT, the scientists steered it with another gathering of local speakers of British English $(n=9)$. The outcomes from the local speakers of English demonstrated that the situations in the WDCT evoked the planned discourse acts. At that point, the WDCT was controlled to the members as the pretest. It took around 40 minutes to finish. The members' reactions were evaluated dependent on a 6-point rating scale created by Taguchi (2006). In light of this rating scale, every reaction got a score from 0 to 5 . This scale takes three parts of discourse act creation into thought: logical propriety, linguistic exactness, and discoursal felicity.

With respect to between rater dependability of scoring, 30 members' pretest papers were evaluated by one of the specialists and a local speaker educator of British English. There was a high relationship coefficient of .92 between the two arrangements of scores. Concerning the interior consistency unwavering quality of the WDCT, the investigation of 40 members' pretest scores uncovered a Cronbach's coefficient Alpha estimation of .90 demonstrating excellent inside consistency dependability.

\section{Procedure}

Three classes of English-significant learners partook in the trial period of this examination. Prior to the treatment, the OPT was directed to the three classes to check their homogeneity as far as EFL capability. As noted over, the aftereffect of one-way between-bunches ANOVA uncovered no noteworthy distinction between the OPT mean scores of these three groups, which showed the homogeneity of these groups as far as EFL capability level. The principal gathering (n = 26) was arbitrarily doled out to the ETR condition, the subsequent gathering $(\mathrm{n}=28)$ was haphazardly doled out to the ITR condition, and the third gathering $(n=26)$ was doled out to the NTR gathering. At that point, the WDCT was directed to the members in all the three groups as the pretest and it took around 40 minutes to finish.

At that point, the three groups got guidance on the discourse demonstrations. The instructional medications were executed for six sessions, each enduring around an hour and a half. Two sessions were given to the guidance of every one of the discourse demonstrations of expressing gratitude toward (sessions 1 and 2), saying 'sorry' (sessions 3 and 4), and won't (sessions 5 and 6). Since the sort of the discourse demonstration (i.e., saying thanks to, saying 'sorry' and cannot) was not a free factor in this examination, the request wherein the three discourse acts were exhibited didn't make a difference.

The guidance for all the three groups was done in Persian and as per the treatment conditions intended for every one of the groups. All the three classes were educated by the primary creator of this investigation who was likewise the teacher of a large portion of the members at college. After the guidance was finished, the WDCT was regulated to the members as the posttest a few days after the last instructional treatment session.

\section{RESULTS}




\section{Results of Normality Tests}

Before conducting any analyses on the proficiency test, pretest, and posttest, it was necessary to check the normality of the distributions. Thus, Kolmogorov-Smirnov test of normality was run on the data obtained from the abovementioned tests. The results are shown in Table 1:

TABLE 1

NORMALITY TEST FOR THE SCORES OF THE THREE GROUPS IN PRETEST AND POST-TEST

\begin{tabular}{cccc}
\hline & & Kolmogorov-Smirnov $^{\text {a }}$ & Sig. \\
\cline { 2 - 4 } & Statistic & df & .092 \\
\hline ETR. Pretest & .201 & 32 & .112 \\
\hline ETR. Posttest & .177 & 32 & .117 \\
\hline ITR. Pretest & .172 & 32 & $.200^{*}$ \\
\hline ITR. Posttest & .115 & 32 & $.200^{*}$ \\
\hline NTR. Pretest & .122 & 32 & .007 \\
\hline NTR. Posttest & .185 & 32 & \\
\hline Note. ETR = explicit task-repetition group, ITR = implicit task-repetition group, NTR = no-input task-repetition group
\end{tabular}

The $p$ values under the Sig. column in Table 1 determine whether the distributions were normal or not. A $p$ value greater than .05 shows a normal distribution, while a $p$ value lower than .05 indicates that the distribution has not been normal. Since all the $p$ values in Table 1 were larger than .05 , it could be concluded that the distributions of scores for the proficiency test, pretest, and posttest obtained from three groups had been normal. It is thus safe to proceed with parametric test (i.e. ANOVA in this case) and make further comparisons between the participating groups.

TABLE 2

DESCRIPTIVE STATISTICS FOR THE WDCT PRETEST SCORES

\begin{tabular}{ccccc}
\hline Groups & $\mathrm{N}$ & Mean & Std. Deviation & Std. Error \\
\hline ETR & 32 & 58.62 & 5.08 & .89 \\
\hline ITR & 32 & 57.09 & 4.26 & .75 \\
\hline NTR & 32 & 56.37 & 4.21 & .74 \\
\hline Total & 96 & 57.36 & 4.58 & .46 \\
\hline
\end{tabular}

To compare the performance of the three groups on the WDCT pretest, a one-way between-groups ANOVA was performed. Table 2 presents the descriptive statistics of the performance of the three groups on the WDCT pretest. Table 2 indicates that, in the WDCT pretest, all the three groups had almost the same performance. Their mean scores are a testimony for our claim.

TABLE 3

ANOVA Results For THE PERFORMANCE OF THE THREE GROUPS ON THE WDCT PRETEST

\begin{tabular}{cccccc}
\hline & Sum of Squares & df & Mean Square & F & Sig. \\
\hline Between Groups & 84.52 & 2 & 42.26 & 2.05 & .134 \\
\hline Within Groups & 1915.71 & 93 & 20.59 & & \\
\hline Total & 2000.24 & 95 & & & \\
\hline
\end{tabular}

One-way between groups ANOVA indicated that the assumption of homogeneity of variances was met in the pretest, $\mathrm{F}=2.052, \mathrm{p}=.134$. The results (see Table 3 ) revealed that there was no statistically significant difference at the $\mathrm{p}<.05$ level in the pretest scores for the three groups. This suggests that the three groups were homogeneous in terms of speech act production ability at the outset of the study.

The reason behind administering the posttest was to see whether there was a difference in speech act production of the learners in the three experimental groups. To this end, the posttest scores of the ETR, ITR and NTR needed to be compared via one-way between-groups ANOVA. The descriptive results of the comparison of the three groups on the posttest are displayed in Table 4. 
TABLE 4

DESCRIPTIVE STATISTICS RESUlts COMPARING ETR, ITR AND NTR MEAN SCORES ON THE POSTTEST

\begin{tabular}{ccccc}
\hline Groups & $\mathrm{N}$ & Mean & Std. Deviation & Std. Error \\
\hline ETR & 32 & 71.84 & 5.75 & 1.01 \\
\hline ITR & 32 & 59.87 & 5.65 & .99 \\
\hline NTR & 32 & 56.93 & 4.58 & .81 \\
\hline Total & 96 & 62.88 & 8.37 & .85 \\
\hline
\end{tabular}

The mean scores of the ETR $(M=71.84)$, ITR $(M=59.87)$, and NTR $(M=56.93)$ were different from one another on the posttest. To figure out whether the differences among these mean scores were significant or not, one needs to check the $p$ value under the Sig. column in the ANOVA table below (Table 5). It should be noted that ANCOVA, using the pretest scores as the covariate, was avoided as the assumption of homogeneity of regression slopes was found to be violated.

TABLE 5

ANOVA RESULTS FOR THE WDCT POSTTEST SCORES

\begin{tabular}{cccccc}
\hline & Sum of Squares & df & Mean Square & F & Sig. \\
\hline Between Groups & 3990.14 & 2 & 1995.07 & 69.50 & .000 \\
\hline Within Groups & 2669.59 & 93 & 28.70 & & \\
\hline Total & 6659.74 & 95 & & & \\
\hline
\end{tabular}

As is could be observed in Table 4.6, there was a statistically significant difference in the posttest scores for three groups on the posttest of WDCT since the $p$ value under the Sig. column was found to be less than the specified level of significance (i.e. $.000<.05$ ), meaning that the three groups significantly differed in terms of speech act production on the posttest. This result could also be clearly noticed in the bar chart that follows (Figure 1).

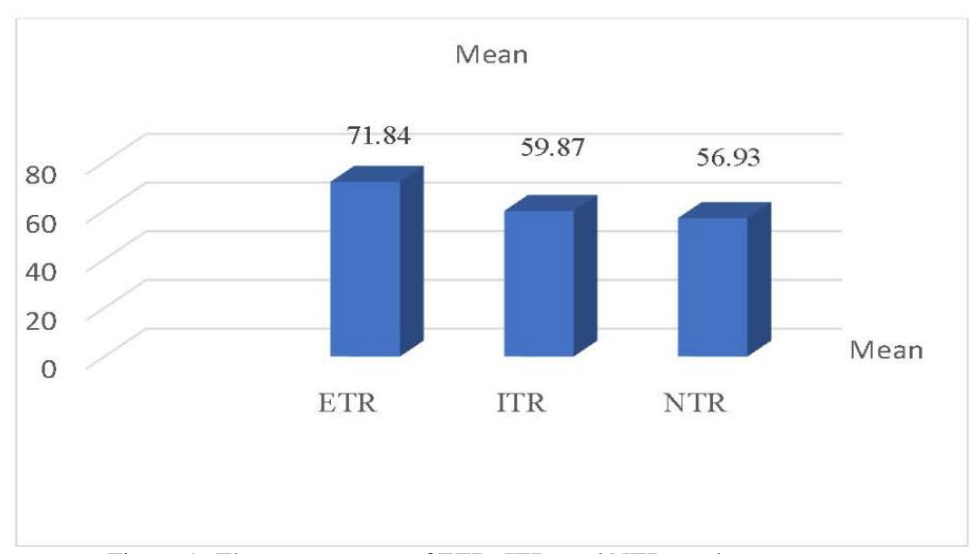

Figure 1: The mean scores of ETR, ITR, and NTR on the posttest

It is clear that ETR learners managed to get higher scores than did ITR learners, who in turn, could obtain higher scores than the NTR learners. Pair-wise comparisons of the groups (in Table 6) reveals which two group/s were significantly different on the posttest.

TABLE 6.

RESULTS OF THE SCHEFFE POST HOC TEST FOR COMPARING THE THREE GROUPS ON THE WDCT POSTTEST $\begin{array}{llll}\text { (I) Groups } & \text { (J) Groups } & \text { Mean Difference (I-J) } & \text { Std. Error }\end{array}$

\begin{tabular}{ccccc}
\hline \multirow{2}{*}{ ETR } & ITR & $11.96^{*}$ & 1.33 & .000 \\
\cline { 2 - 5 } & NTR & $14.90^{*}$ & 1.33 & .000 \\
\hline \multirow{2}{*}{ ITR } & ETR & $-11.96^{*}$ & 1.33 & .000 \\
& NTR & 2.93 & 1.33 & .096 \\
\hline \multirow{2}{*}{ NTR } & ETR & $-14.90^{*}$ & 1.33 & .000 \\
& ITR & -2.93 & 1.33 & .096 \\
\cline { 2 - 5 }
\end{tabular}

*. The mean difference is significant at the 0.05 level.

In the top line, it could be seen that the contrast between ETR $(M=71.84)$ and ITR $(M=59.87)$ was measurably critical since the Sig. worth relating to this examination $(p=.000)$ was under .05 . This implies utilizing unequivocal task redundancy could prompt a noteworthy impact on the discourse demonstration creation. In like manner, ETR 
students' mean score $(M=71.84)$ was altogether higher than that of NTR students $(M=56.93)$ as a result of the way that the $\mathrm{p}$ worth identified with this correlation was .000 , which is lower than the essentialness level. At long last, the correlation of ITR $(M=59.87)$ and NTR $(M=56.93)$ uncovered that the two procedures of understood task reiteration and no-input task-redundancy utilized for instructing discourse acts to EFL students didn't contrast altogether because of the way that the $\mathrm{p}$ worth relating to the examination of these two groups (for example .096) surpassed the centrality level. To summarize, As showed in Table 6, the consequences of Scheffe test uncovered that the ETR gathering performed altogether superior to anything the ITR and the NTR groups. Be that as it may, there was no factually noteworthy distinction between the ITR and NTR groups.

These outcomes lead to the accompanying response to the examination question of 'Do diverse assignment reiteration conditions (ETR, ITR, and NTR) impactsly affect delivering discourse act among Iranian development EFL students?' The appropriate response is confirmative. The ETR, ITR, and NTR conditions affect EFL students' discourse demonstration creation.

At that point, the student' execution was analyzed as far as contrasts over the two organization of the WDCT. The reason for existing was to check whether there were any measurably critical changes in the students' presentation from the pretest to the posttest. As exhibited in Table 7, the presentation of the ETR gathering improved from the pretest (M $=58.62)$ to the posttest $(\mathrm{M}=71.84)$. So also, there was an expansion in the mean score of the ITR bunch from the pretest $(M=57.09)$ to the posttest $(M=59.87)$, though the mean score of the NTR gathering didn't factually transform from the pretest $(M=56.37)$ to the posttest $(M=56.93)$.

TABLE 7

PAIRED SAMPLES STATISTICS (PRE AND POST-TESTS OF THREE GROUPS)

\begin{tabular}{llllll}
\hline & & Mean & N & Std. Deviation & Std. Error Mean \\
\hline Pair 1 & ETR Post & 71.84 & 32 & 5.75 & 1.01 \\
\cline { 2 - 6 } & ETR. Pre & 58.62 & 32 & 5.08 & .89 \\
\hline Pair 2 & ITR. Post & 59.87 & 32 & 5.65 & .99 \\
\cline { 2 - 6 } & ITR. Pre & 57.09 & 32 & 4.26 & .75 \\
\hline Pair 3 & NTR. Post & 56.93 & 32 & 4.58 & .81 \\
\cline { 2 - 6 } & NTR. Pre & 56.37 & 32 & 4.21 & .74 \\
\hline
\end{tabular}

Matched sample t-test results uncovered that the ETR gathering made a measurably critical increase from the pretest to the post test. Likewise, in the ITR gathering, the expansion in the mean score from the pretest to the posttest was factually huge. Notwithstanding, in the NTR gathering, the change from the pretest to the posttest was not measurably huge. Table 8 shows the consequences of the t-test investigation. Along these lines, it creates the impression that the ETR and ITR instructional conditions worked effectively in encouraging discourse acts to the EFL students, while the NTR condition didn't prompt a factually critical change in the students' presentation.

TABLE 8

RESULTS OF PAIRED SAMPLES T-TEST FOR THE THREE GROUPS ON PRETEST AND POSTTEST

\begin{tabular}{|c|c|c|c|c|c|c|c|}
\hline & & Mean & Std. Deviation & Std. Error Mean & $\mathrm{t}$ & df & Sig. (2-tailed) \\
\hline Pair 1 & ETR. Post - ETR. Pre & 13.21 & 7.52 & 1.32 & 9.94 & 31 & .000 \\
\hline Pair 2 & ITR. Post - ITR. Pre & 2.78 & 5.08 & .89 & 3.09 & 31 & .004 \\
\hline Pair 3 & NTR. Post - NTR. Pre & .56 & 1.83 & .32 & 1.73 & 31 & .092 \\
\hline
\end{tabular}

\section{DISCUSSION}

The present examination researched the impacts of output-based task reiteration joined by contribution in addition to metapragmatic data, outwardly upgraded contribution in addition to CR, and no contribution on EFL students' discourse demonstration creation. The outcomes showed that the exhibition of ETR and ITR groups, however not that of the NTR gathering, fundamentally improved from the pretest to the posttests. Moreover, the ETR condition was observed to be essentially more viable than the ITR and NTR conditions in upgrading the students' discourse demonstration generation capacity.

The primary point to talk about is the potential utility of task redundancy in L2 (pragmatics) guidance. The aftereffects of the present investigation are perfect with the discoveries of past examinations on assignment reiteration (e.g., Ahmadian, 2011; Bygate and Samuda, 2005), which presumed that redundancies of a similar task can encourage students' L2 execution and obtaining. In such manner, Takimoto (2012), drawing on critical thinking assignments, likewise inferred that indistinguishable task redundancy and task type reiteration groups outflanked the control bunch in his examination. It should be noticed that Takimoto concentrated on the impacts of information handling task reiteration. 
In any case, the present investigation showed that output creation task redundancy can be a successful instructional procedure in L2 discourse act guidance on the off chance that it is joined by info combined with metapragmatic data or outwardly improved information combined with CR. This is in accordance with Sheppard's (2006) finding that output age task redundancy can advance L2 improvement on the off chance that it is joined by info or criticism.

The subsequent point to be noted is the job of output. The kind of the task used in this investigation included output age by the students. All together for successful figuring out how to happen, students need to utilize the recently got language in their very own creation (Tahmasbi, Hashemifardnia, \& Namaziandost, 2019). As Bygate and Samuda (2005) properly contend "a typical learning and encouraging issue is to get students to incorporate information that is accessible to them into their dynamic language use" (p. 270). The output age assignments utilized in this examination gave an opportunity to the students to apply their recently known down to earth learning in their language creation. Besides, after their first execution of output age assignments, the students in the ETR and ITR conditions were presented to sober minded parts of language through information combined with metapragmatic data and information combined with visual upgrade and CR individually. The second execution of the task gave a chance to the students to work on utilizing this new businesslike learning. Almost certainly, the combination of the pragmalinguistic and sociopragmatic information into the second execution of the task fundamentally added to the students' businesslike advancement (Shakibaei, Shahamat, \& Namaziandost, 2019).

Moreover, the adequacy of output age tasks utilized in this examination can be clarified regarding output speculation and the three elements of output (Swain \& Lapkin, 1995): (1) the output may have made the students see the holes in their very own down to earth information, (2) their first output may have empowered the students to create sober minded theories and test them against the info they got before the second execution of the assignment. It should be noticed that this kind of theory testing couldn't happen in the NTR bunches as this gathering didn't get any commonsense contribution after the principal execution of the task, and (3) the third work that Swain alludes to is the utilization of metalanguage. In the present investigation, the students in the ETR, ITR, and NTR groups occupied with metapragmatic discourse before the second execution of the task.

Rose and Ng Kwai-fun (2001) contend that inductive guidance and guided revelation can bring about more disarray than perception. In any case, the consequences of the present investigation uncovered that the ITR condition, rather than the NTR condition, fundamentally prompted L2 down to business improvement from the pretest to the posttest. This might be represented by the operationalization of understood guidance (i.e., students' introduction to outwardly improved info and their commitment in CR tasks) and the output-based task reiteration that the students occupied with. As such, the improvement in the ITR gathering might be ascribed to the joint impacts of output creation, visual upgrade, and CR exercises the students occupied with (Abedi, Namaziandost, \& Akbari, 2019).

The present investigation additionally uncovered the benefit of the ETR bunch over the ITR gathering. This is in accordance with the discoveries of most of past examinations that demonstrated the predominance of unequivocal educating over verifiable L2 pragmatics guidance (Rose, 2005; Ziafar \& Namaziandost, 2019). Taguchi (2015) found that unequivocal structure centered guidance including metapragmatic data was commonly more successful than its understood partner notwithstanding when the information is made striking through upgrade systems. So also, the aftereffects of the present investigation demonstrated that notwithstanding when understood and express instructional methodologies are coordinated into output-based task redundancy exercises, the verifiable strategy isn't as viable as its certain partner. In spite of the fact that the ETR gathering contrasted from the ITR bunch in that lone the ETR gathering was given metapragmatic data, the predominance of the ETR bunch over the ITR gathering might be credited to the mix of the highlights related with the ETR condition instead of metapragmatic data all alone (Ziafar \& Namaziandost, 2019). The arrangement of metapragmatic data, introduction to the plain configuration of writings, structure correlation, and output creation task redundancy, inside and out, might have prompted the students' attention to the discourse demonstration highlights. At the end of the day, the blend of these variables may have empowered the students in ETR gathering to achieve structure work setting mappings and disguise the related sober minded information more adequately than the ITR gathering.

\section{CONCLUSION}

This examination meant to research the impacts of output put together task reiteration with respect to EFL students' discourse demonstration generation. The outcomes not just affirm the openness to instruction of discourse act highlights, yet in addition show the utility of output-based assignment reiteration in L2 discourse act guidance. The outcomes uncovered that output-based task redundancy can be viable on the off chance that it is joined by contribution in addition to metapragmatic data or outwardly improved contribution in addition to CR assignments. At the end of the day, reiteration of output age tasks joined by just students' appearance and metatalk, without presenting the students to any information, appears not to be successful in upgrading students' discourse demonstration creation capacity.

As Taguchi (2015) contends, understood ways to deal with L2 pragmatics guidance can be similarly as successful as unequivocal instructing gave that they attract students' regard for structure work setting mappings. In the output-based assignment reiteration exercises used in this investigation, a lot of components appeared to attract the students' regard for structure work setting mappings. The students got situations dependent on which they were required to build writings. Moreover, they occupied with CR tasks and they were allowed to thoroughly analyze their very own output 
with the outwardly improved content including the objective even minded highlights. The situations, output, outwardly improved info, CR and structure examination exercises were relied upon to expand the remarkable quality of the down to earth parts of the information the students got in the ITR gathering and to make understood guidance as successful as express educating. Indeed, even with such factors used to upgrade the remarkable quality of the realistic highlights in the information and to advance structure work setting mappings, understood guidance didn't function as successfully as express instructing.

\section{REFERENCES}

[1] Abedi, P., Keshmirshekan, M. H., \& Namaziandost, E. (2019). The comparative effect of flipped classroom instruction versus traditional instruction on Iranian intermediate EFL learners' English composition writing. Journal of Applied Linguistics and Language Research, 6(4), 43-56.

[2] Abedi, P., Namaziandost, E., \& Akbari, S. (2019). The impact of flipped classroom instruction on Iranian upper-intermediate EFL learners' writing skill. English Literature and Language Review, 5(9), 164-172

[3] Ahmadian, M. J. (2011). The effect of 'massed' task repetitions on complexity, accuracy and fluency: Does it transfer to a new task? The Language Learning Journal, 39 (3), 269-280.

[4] Allen, D. (2004). Oxford placement test 1. Oxford: Oxford University Press.

[5] Azadi, G., Biria, R., \& Nasri, M. (2018). Operationalising the Concept of Mediation in L2 Teacher Education. Journal of Language Teaching and Research, 9(1), 132-140.

[6] Birjandi, P., \& Siyyari, M. (2010). Self-assessment and peer-assessment: A comparative study of their effects on writing performance and rating accuracy. Iranian Journal of Applied Linguistics, 13 (1), 23-45.

[7] Bygate, M., \& Samuda, V. (2005). Integrative planning through the use of task repetition. In R. Ellis (Ed.), Planning and task performance in a second language (pp. 37-74). Amsterdam: John Benjamins.

[8] Cheng, S. W. (2005). An exploratory cross-sectional study of interlanguage pragmatic development of expressions of gratitude by Chinese learners of English. Unpublished PhD dissertation, University of Iowa, USA.

[9] Eisenstein, M., \& Bodman, J. W. (1986). "I very appreciate": Expressions of gratitude by native and nonnative speakers of American English. Applied Linguistics, 7 (2), 167-185.

[10] Ellis, R. (2005). Planning and task-based performance: Theory and research. In R. Ellis (Ed.), Planning and task performance in a second language (pp. 3-34). Amsterdam: John Benjamins.

[11] Ellis, R. (2009). The differential effects of three types of task planning on the fluency, complexity and accuracy in L2 oral production. Applied Linguistics, 30 (4), 474-509.

[12] Hashemifardnia, A., Namaziandost, E., \& Sepehri, M. (2018). The effectiveness of giving grade, corrective feedback, and corrective feedback-plus-giving grade on grammatical accuracy. International Journal of Research Studies in Language Learning, 8 (1), 15-27.

[13] Hashemifardnia, A., Namaziandost, E., Shafiee, S. (2018). The Effect of Implementing Flipped Classrooms on Iranian Junior High School Students' Reading Comprehension. Theory and Practice in Language Studies, 8(6), 665-673.

[14] Hosseini, E. Z., Nasri, M., \& Afghari, A. (2017). Looking beyond teachers' classroom behavior: novice and experienced EFL teachers' practice of pedagogical Knowledge to Improve Learners' Motivational Strategies. Journal of Applied Linguistics and Language Research, 4(8), 183-200

[15] House, J. (1996). Developing pragmatic fluency in English as a foreign language: Routines and metapragmatic awareness. Studies in Second Language Acquisition, 18 (6), 225-253.

[16] Keshmirshekan, M. H., Namaziandost, E., \& Pournorouz, M. (2019). The Impacts of Creative Writing Activities on Iranian EFL Learners' Progress in Writing, Writing Dispositions: Focus on Attitude to English Course. EPH - International Journal of Educational Research, 3(9), 12-22.

[17] Li, S. (2012). The effects of input-based practice on pragmatic development of requests in L2 Chinese. Language Learning, 62 (2), 403-438.

[18] Mirshekaran, R., Namaziandost, E., \& Nazari, M. (2018). The Effects of Topic Interest and L2 Proficiency on Writing Skill among Iranian EFL Learners. Journal of Language Teaching and Research, 9(6), 1270-1276.

[19] Namaziandost E., \& Nasri, M. (2019a). A meticulous look at Long's (1981) interaction hypothesis: does it have any effect on speaking skill? Journal of Applied Linguistics and Language Research, 6(2), 218-230.

[20] Namaziandost E., \& Nasri, M. (2019b). The impact of social media on EFL learners' speaking skill: A survey study involving EFL teachers and students. Journal of Applied Linguistics and Language Research, 6(3), 199-215.

[21] Namaziandost, E., \& Nasri, M., Rahimi Esfahani, F., \& Keshmirshekan M. H. (2019). The impacts of spaced and massed distribution instruction on EFL learners' vocabulary learning. Cogent Education, 6: 1661131. https://doi.org/10.1080/2331186X.2019.1661131.

[22] Namaziandost, E., Abedi, P., \& Nasri, M. (2019). The Role of Gender in the Accuracy and Fluency of Iranian Upperintermediate EFL Learners' L2 Oral Productions. Journal of Applied Linguistics and Language Research, 6(3), 110-123

[23] Namaziandost, E., Nasri, M., \& Keshmirshekan, M. H. (2019). Cohesive conjunctions in applied linguistics research articles among Iranian and non-Iranian researchers: A comparative corpus-based study. Journal of English Language Studies, 4(2), 101 -119 .

[24] Namaziandost, E., Nasri, M., \& Rahimi Esfahani, F. (2019a). Pedagogical Efficacy of Experience-Based Learning (EBL) Strategies for Improving the Speaking Fluency of Upper-intermediate Male and Female Iranian EFL Students. International Journal of Research in English Education, 4(2), 29-41.

[25] Namaziandost, E., Rahimi Esfahani, F., Nasri, M., \& Mirshekaran, R. (2018). The Effect of Gallery Walk Technique on Preintermediate EFL Learners' Speaking Skill. Language Teaching Research Quarterly, 8, 1-15. 
[26] Nasri, M. \& Biria, R. (2017). Integrating multiple and focused strategies for improving reading comprehension and 12 lexical development of Iranian intermediate EFL learners. International Journal of Applied Linguistics \& English Literature, 6(1), 311-321.

[27] Nasri, M., Biria, R., \& Karimi, M. (2018). Projecting Gender Identity in Argumentative Written Discourse. International Journal of Applied Linguistics \& English Literature, 7(3), 201-205.

[28] Nasri, M., Namaziandost, E., \& Akbari, S. (2019). Impact of pictorial cues on speaking fluency and accuracy among Iranian pre-intermediate EF learners. International Journal of English Language and Literature Studies, 8(3), 99-109

[29] Pica, T. (2011).). Second Language acquisition research: Applied and applicable orientations to practical questions and concerns. In E. Hinkel (Ed.), Handbook of research in second language teaching and learning (Vol. 2, pp.257-273). New York: Routledge.

[30] Rose, K. R. (2005). On the effects of instruction in second language pragmatics. System, 33(3), 385-399.

[31] Rose, K. R., \& Ng Kwai-fun, C. (2001). Inductive and deductive teaching of compliments and compliments responses. In K. R. Rose \& G. Kasper (Eds.), Pragmatics in language teaching (pp. 145-170). New York: Cambridge University Press.

[32] Shakibaei, G., Shahamat, F., \& Namaziandost, E. (2019). The effect of using authentic texts on Iranian EFL learners' incidental vocabulary learning: The case of English newspaper. International Journal of Linguistics, Literature and Translation (IJLLT), 2(5), 422-432

[33] Sheppard, C. (2006). The effects of instruction directed at the gaps second language learners noticed in their oral production. Doctoral Dissertation, University of Auckland, New Zealand.

[34] Swain, M., \& Lapkin, S. (1995). Problems in output and the cognitive processes they generate: a step towards second language learning. Applied Linguistics, 16 (3), 371-391.

[35] Taguchi, N. (2015). Instructed pragmatics at a glance: Where instructional studies were, are, and should be going. Language Teaching, 48(2), 1-50.

[36] Tahmasbi, S., Hashemifardnia, A., \& Namaziandost, E. (2019). Standard English or world Englishes: Issues of ownership and preference. Journal of Teaching English Language Studies, 7(3), 83-98.

[37] Tahmasbi, S., Hashemifardnia, A., \& Namaziandost, E. (2019). Standard English or world Englishes: Issues of ownership and preference. Journal of Teaching English Language Studies, 7(3), 83-98.

[38] Tajeddin, Z., \& Bagherkazemi, M. (2014). Short-term and long-term impacts of individual and collaborative pragmatic output on speech act production. TELL, 8(1), 39-164.

[39] Tajeddin, Z., Keshavarz, M. H., \& Zand-Moghadam, A. (2012). The effect of task-based language teaching on EFL Learners' pragmatic production, metapragmatic awareness, and pragmatic self-assessment. Iranian Journal of Applied Linguistics, 15 (2), 139-166.

[40] Takimoto, M. (2009). The Effects of input-based tasks on the development of learners' pragmatic proficiency. Applied Linguistics, 30 (3), 1-25.

[41] Takimoto, M. (2012). Assessing the effects of identical task repetition and task type repetition on learners' recognition and production of second language request downgrades. Intercultural Pragmatics, 9 (1), 71-96.

[42] Tateyama, Y. (2001). Explicit and implicit teaching of pragmatic routines. In K. R. Rose \& G. Kasper (Eds.), Pragmatics in language teaching (pp. 200-222). Cambridge: Cambridge University Press.

[43] Van den Branden, K. (2007). Second language education: Practice in perfect learning conditions? In R. M. DeKeyser (Ed.), Practice in a second language: Perspectives from applied linguistics and cognitive psychology (pp. 161- 179). Cambridge: Cambridge University Press.

[44] Ziafar M., \& Namaziandost, E. (2019). Linguistics, SLA and lexicon as the unit of language. International Journal of Linguistics, Literature and Translation (IJLLT), 2(5), 245-250

Parisa Etemadfar was born in Isfahan Iran. She is an MA student in TEFL at Shahrekord University, Iran. Her areas of interest are vocabulary learning and teaching, Teaching language skills.

Ehsan Namaziandost was born in Shiraz Province of Iran in 1985. He holds an MA degree in TEFL from Islamic Azad University of Ahvaz. Now, he is Ph.D. candidate of TEFL at Islamic Azad University, Shahrekord, Iran. His main interests of research are second language acquisition, EFL teaching and testing, teaching language skills, and language learning strategies. His research papers and articles have been published by different international journals.

Reza Banari was born in Khouzestan Province of Iran. He holds an MA degree in TEFL. He is currently finished his PhD in TEFL at Shahid Chamran University of Ahvaz, Iran. His main interests of research are discourse analysis, genre-based language teaching, and genre analysis. His research papers have been published by various international journals. 